\title{
A new funding scheme for MSW management to support WtE program
}

\author{
Farizal $^{1, *}$, Nadya Amalin ${ }^{1}$, and Amar Rachman ${ }^{1}$ \\ ${ }^{1}$ Department of Industrial Engineering, Faculty of Engineering, Universitas Indonesia, Depok 16424
}

\begin{abstract}
Among many approaches to manage municipal solid waste (MSW), waste to energy (WtE) program through running a landfill gas plant is believed the best way. It deals with waste and energy problems simultaneously. However, even though it offers inevitable benefits, in Indonesia $\mathrm{WtE}$ program implementation is stagnant. This study proposes an alternative funding scheme to run the program, i.e. based on resident participation. The study used willingness to pay from Contingent Valuation Method to disclose the participation level. For the purpose, a case study was taken place at City of Depok, West Java Province. The result reveals that the proposed funding scheme is an applicable way for the program. As much as $86 \%$ of Depok resident were willing to participate funding the project with the participation range of 20,000 to 200,000 IDR per month. The percentage is even higher, $88 \%$, if there is an incentive such as electricity bill discount to the participants.
\end{abstract}

\section{Introduction}

Municipal solid waste (MSW) problem is a global problem especially in big cities. In this case, population growth and economic prosperity will directly affect the MSW production. According to [1], MSW production is proportional to the number of the population. This means as the population grows the waste production becomes larger. MSW production also depends on life style of the people [2]. Generally, city's residents are producing more waste than villagers. These instances make urban MSW problems are difficult to be solved. On the other side, lack of proper management of the waste could pose many significant threats to human health and the environment.

In many cities of Indonesia, MSW production has similar trend. According to a report from the State Ministry for Environment (KLH), in 2012 MSW production of 377 cities was 241 million cubic meter per month. To tackle MSW problem, many programs have been introduced including 3R (Reduce, Reuse, and Recycle). However, at many of those cities at most only $60 \%$ of MSW were managed properly. Leaving the rest $40 \%$ untreated, burned or dumped in open area or river [3]. To provide a good waste management, money

* Corresponding author: farizal@eng.ui.ac.id 
collected to fund the activities should be big enough to cover all expenses. However, according to [4], tipping fees collected to fund waste related activities are very limited and it is almost impossible to raise it up.

Economic and population growth will also directly affect energy consumption. In the last ten years (2003-2013), energy consumption in Indonesia has increased from 79 to 134 million ton oil equivalent (TOE). The consumption grows on average 5.5\% per year. For electricity, the consumption continues to increase with an average growth rate about $7.2 \%$ per year. However, electrical power generation only grows on average $5.1 \%$ per year [5]. This fact shows that there is a shortage electricity supply in Indonesia.

Indonesian government has set a target for energy mix in 2025 that consists of at least $23 \%$ of renewable energy [6]. Among potential renewable energy sources in Indonesia, one alternative is biogas which can be generated from biomass and/or MSW. Methane gas is produced when a pile of MSW decomposed. This gas, further, can be converted to electricity through a landfill gas plant (LFGP) project. According to US EPA, as June 2017 there exist 634 LFGP projects at America. On average a LFGP generates $3 \mathrm{MWe}$ and 15.5 thousand cubic meter per day of methane gas for direct application [7]. As addition to the source of energy, utilizing biogas from MSW can improve human wellbeing. It can improve city sanitation, reduce smoke, and job creation. Bioenergy can also improve quality of the environment through improving water standard, conserving resources especially trees, and reducing greenhouse gas emissions [8].

Indonesia's territory spans over three different time zones. Currently it has 438 landfills [9]. A study by [10] showed that LFG can contribute up to $9 \%$ of Indonesia energy mix. Even the study showed that LFGP is one possible solution for a better MSW management and energy mix problem in Indonesia. But this country has only a few LFGP. Table 1 clearly shows Indonesia's seven LFGPs [11]. Investors are reluctant to invest their money on this project nor the government. In a study using optimization approach, [12] showed that government funding limitation to waste to energy (WtE) program will drive the program just be able to handle $12.37 \%$ of total Indonesian waste and generate 1,230 $\mathrm{GWh}$ of electricity.

Table 1. Existing LFGP in Indonesia.

\begin{tabular}{|c|c|c|c|}
\hline No & LFGP Location & Capacity, MW & Developer/Owner \\
\hline 1 & Bantar Gebang, Bekasi & $5 \times 2$ & OVI Energy Inc. \\
\hline 2 & Sunter, Jakarta & 14 & Jakarta Municipality \\
\hline 3 & Sumur Batu, Bekasi & 3 & Gikoko Kogyo Inc. \\
\hline 4 & Gedebage, Bandung & 7 & Bandung Indah Lestari Inc. \\
\hline 5 & Telaga Punggur, Batam & 14 & Batam Authority \\
\hline 6 & Sukawinatan, Palembang & 0.5 & DGNREEC \\
\hline 7 & Benowo, Surabaya & 9 & Sumber Organic Inc. \\
\hline
\end{tabular}

This study proposes the applicability of financing LFGP project through resident involvement. The concept was checked at the City of Depok, West Java Province. By so doing, it will light up a way to promote a better MSW management through implementing more LFGP in Indonesia.

\section{Methodology}

\subsection{Proposed Funding Scheme}

Depending on the nature of a project, the project is basically funded by government and/or private entity. A public utility project, such as bridge and highway construction, which 
usually does not generate income (or profit) will be funded by the government [13]. But, this type of project have to be developed since the project gives benefit such as opening and connecting rural access, saving travel time and life, as well as providing better environment. LFG facility belongs to this kind of project, so the money to erect and run the facility will be handled by the government. Since LFG facility can also generate income, through implementing tipping fee to its users, LFG facility can also be managed and run by private entity. These two financing schemes also exist in Indonesia (See Table 1).

In the case where there exists competing priority in funding public projects, a certain public utility project might not get sufficient funding. In the worst case it will not be funded at all. In the case of profit projects, a project might not be executed if the project is less attractive (in the sense that it generates less profit) than project competitor or if it is a risky project. On these situations, another type of financing scheme which involved citizen participation in funding the project may be an option. This type of financing is called as crowdfunding.

[14] describes crowdfunding as individual or collective efforts to fund their venture by donating a small amount of money they agree to pay. This funding usually draws from a relatively large number of people collected through the internet. Crowdfunding can be performed individually such as on financing solar rooftop at Perth, Australia [15]. However, as a new model of financing crowdfunding is not really mature due to the number of participants is not big enough to gather sufficient fund to finance the project or regulation platform is not established yet. These events occur at the Netherlands [16]. Eight case studies of crowdfunding models have been investigated by [17]. The studies include reward-based crowdfunding, donation-based, lending-based, debenture, and equity-based crowdfunding. Effort to further investigate crowdfunding potential was carried out by [18]. They proposed a business model innovation that simulated synergies and differences in doing crowdfunding. As the result, they found that equity-crowdfunding is a suitable form for energy co-operatives.

In this study, crowdfunding for LFGP project was introduced and investigated. But, the proposed scheme is different with previous exercised crowdfunding at least on three aspects. First is from the type of funding and duration. At already exercised crowdfunding the participants finance the capital cost of the project, while the proposed model on this study is for funding the initial project investment costs and also funding for the entire project costs during the whole project life time; for the LFGP the life time is assumed for 20 years. The second thing is from the nature of the contribution. On common crowdfunding the participants just pay for the amount they called for. On this proposed scheme, the participants actually have already paid a certain amount of money, called as tipping fee, to get a service for their MSW, then they have been asked to contribute more for getting better benefit that will not only go back to themselves but for the whole community. From the participant view, this model calls to participate people who live on the region where the landfill is located so that the proposed model called as Resident Based Financial Model.

For the purpose evaluating the applicability of this proposed model and to disclose how far the resident participation is, willingness to pay (WTP) method was used. WTP survey was conducted to the residents of Depok to find out how much extra money they are willing to pay to achieve a better waste management.

\subsection{Willingness to Pay}

WTP has been used in many waste retribution studies. Among them are WTP for waste sorting management improvement [19, 20], WTP for repairment of waste processing construction [21], and WTP to undertake recycle program [22]. WTP in rural areas that 
have not been connected to electricity has been conducted by [23]. While WTP for the purchase of electricity generated from MSW has been performed by [24].

For the purpose, WTP questionnaire was designed based on [20]. The questionnaire is divided into five parts. The first part is about respondents' characteristics. This part is asking the respondents about their gender, education, age, occupation and income. They are also being asked about their house status whether own or rented. The second part is asking respondents' knowledge about the impacts of the waste if it is not handled properly and their awareness on the current condition of MSW problem in Depok. The impacts of improper waste management being asked include methane gas emission and its impact on green house gas emission, leachate production and its impact on ground water pollution, and potency to use methane gas to generate electricity. In this part the respondents were also asked about Depok waste management practice including the waste collecting frequency in a week, tipping fee and their involvement on recycling their waste. This part is closed by asking the respondents whether they satisfied or not with the current condition. On WTP part three, the respondents is informed about the actual situations of Depok's landfill and Depok waste management and a possible solution to the problem. In this study the solution offered is to erect LFGP; the benefit of the project and the funding needed for the project. The next part, the respondents will be asked about how much money they like to contribute to make the proposed solution be implemented. The questionnaire is closed by the fifth part by questioning the respondents how much they will give if there is a benefit they will get due to their contribution. The benefit for example is electricity discounts for their household.

To disclose residents of Depok willingness to participate at LPGP project, in total 29 questions, beside WTP part three questions, have been developed. Most of the questions are in the form of multiple choice with three to four answers. While part 3 is a short chapter on Depok MSW real situation and LFGP Project.

\section{Result and discussion}

City of Depok is one of the fast growing suburban cities that support the Capital City of Jakarta. Its soil covers $200.29 \mathrm{Km}^{2}$ wide. Due to its strategic location, Depok's population increases with the rate on average $4.1 \%$ per year [27]. According to [27], on the year of 2014 , the city has $1,962,160$ residents with 570,491 households that spreading within its 11 districts.

To manage its 11 districts' MSW, Depok utilizes one landfill with three dumping chambers. Currently, two of the chambers are already full. Struggling with its close to overcapacity landfill, the city is actively promoting its citizens to participate to $3 \mathrm{R}$ program (Reduce, Reuse, Recycle) to reduce the amount of MSW dumped to its only landfill and at the same time progressing to find a new location for its landfill.

WTP survey was carried out to reveal whether Depok residents are willing to finance their new landfill equipped with LFGP project by paying some amount of money as addition to their regular tipping fee they already pay monthly. WTP survey on this research was conducted by direct interview and online questionnaire using Google Doc facility. To determine the sample size, Slovin formula was used [25]. Since City of Depok residents are 570,491 households [26], using sampling error of $10 \%$, the sample size required is 100 . The sample size was then stratified according to the demographic of districts of Depok.

Totally 169 respondents were participated on this survey. This number is more than 1.5 times of the number of participants needed. Number of WTP respondents participated on this survey and target respondent for each district are shown on Figure 1. The figure clearly shows that the number of respondents for each district is majority more than the 
number of respondents needed. Only two districts, Bojongsari and Tapos, have the number of respondents the same as their target.

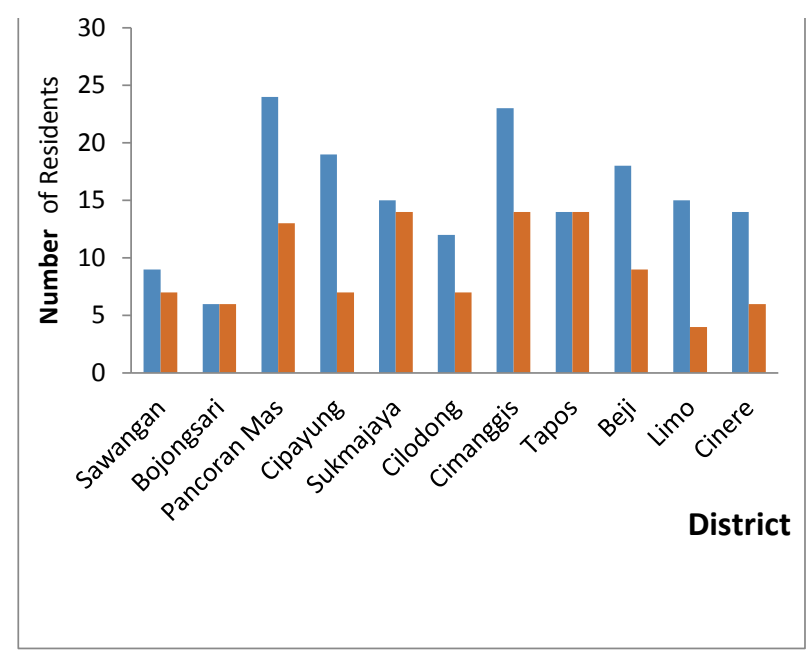

Fig. 1. Number of WTP respondents (blue bar) and target for each district of Depok.

Figure 2 shows WTP value and its percentage for no electricity discount scenario. The figure clearly shows that the value the residents are willing to pay are spreading between the range of 20,000 to 100,000 IDR with the peak of 20,000 to 50,000 IDR. This means the most preferred WTP value is in the range of 20,000 to 50,000 IDR. Surprisingly enough, the graph resembles a bell shape curve with a right tail. The curve tells that more residents are willing to pay for higher contribution; $27 \%$ as oppose to $16 \%$ of lower contribution. In total $86 \%$ of Depok residents are willing to pay more to get a better waste management for their city.

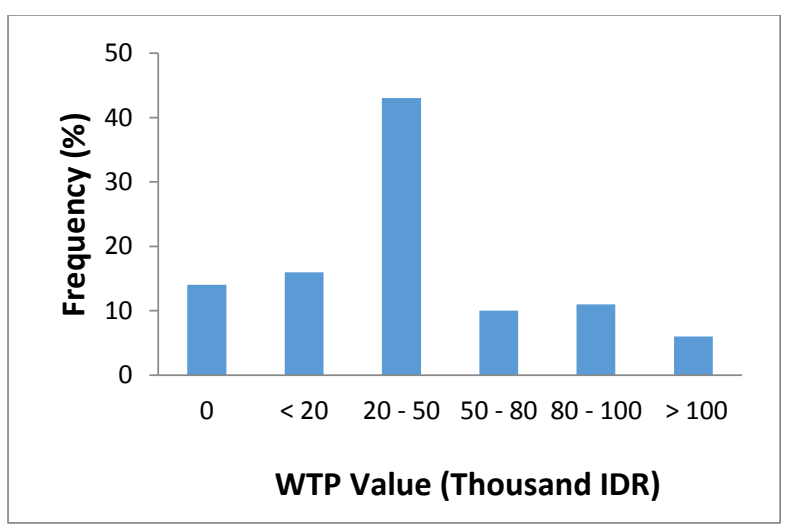

Fig. 2. WTP value without electricity discount scenario.

Figure 3 shows that in electricity discount scenario, the number of residents supporting the project increases to $88 \%$. The figure also shows the most preferred value shifted from 20,000-50,000 to 50,000-80,000 IDR. As addition to the value shifted, the percentage of the respondent belong to this most preferred segment is also increased; from $43 \%$ to $57 \%$. 
The highest value to pay also moves to 150,000 IDR. On this scenario, the graph is completely right tailed which means 50,000 to 80,000 is the lowest value the residents like to contribute. From this information, it is clear that Depok residents are willing to pay more if there is a direct benefit for them such as electricity discount.

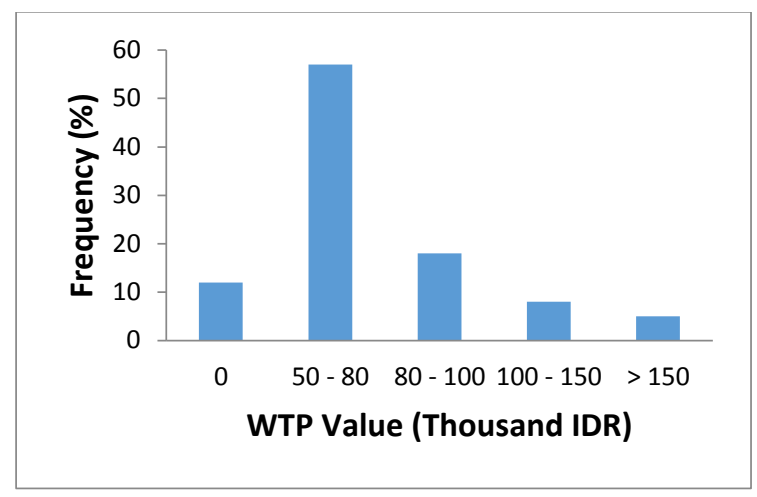

Fig. 3. WTP value with electricity discount scenario.

From these findings, it can be inferred that most Depok residents are aware of the negative impacts of MSW if it is not managed properly. This awareness drives them to participate financing the LFGP.

For the WTP value with electrical discount scenario, the question is how much discount the residents are expected to receive? Figure 4 shows that majority of the residents $(70 \%)$ are expected to receive electricity discount of 100,000 IDR or less and even $20 \%$ of them do not expect any financial return due to their contribution at all. This finding support the statement that Depok residents' awareness and sense of responsibility toward the environment is the main driver of their willingness to pay instead of getting financial discount.

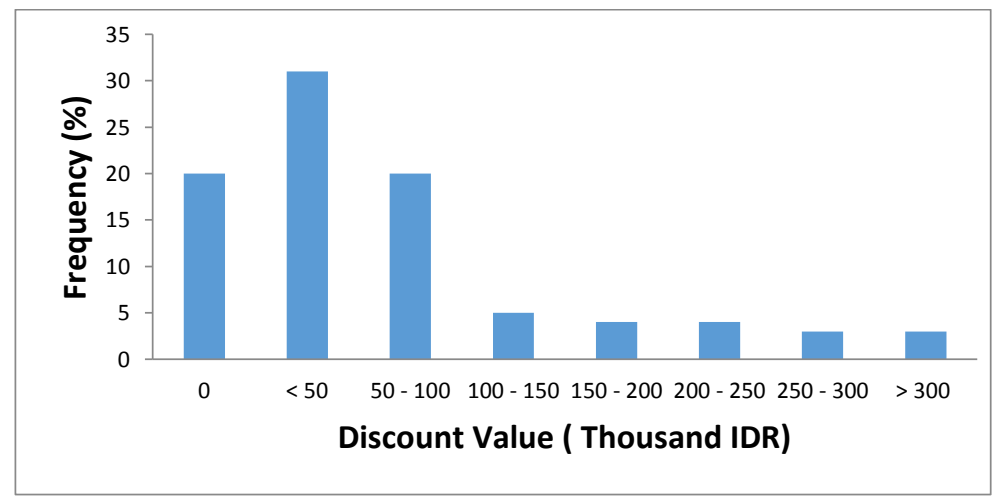

Fig. 4. Expected electricity discount.

This finding is not surprising. Majority of Depok residents are well educated with relatively good income as shown on Figures 5 and 6 .. Figure 5 shows clearly that more than $80 \%$ of the respondents are college graduated. While Figure 6 shows only $22 \%$ of the respondents have monthly income less than 3 million IDR. The rest eighty percent have income more than that amount. This information indicates that majority of Depok residents 
are in a good financial condition. This finding is in line with previous studies such as the 2005-2008 survey on 47 counties by [28, 29].

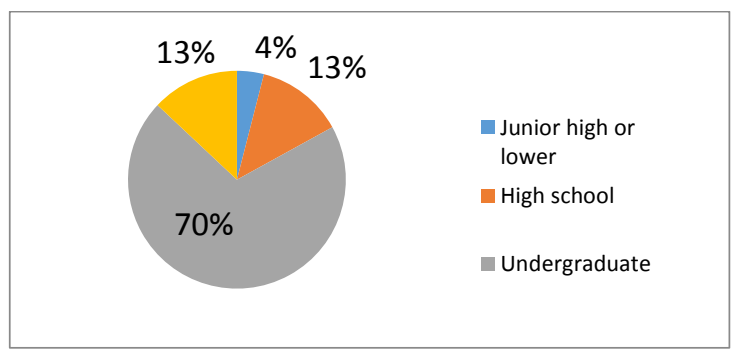

Fig. 5. WTP respondent education level.

Further investigation on the answers of WTP Part 2 reveal that close to $50 \%$ of the respondent are knowledgeable about the MSW impact on green house gas emission and environment.

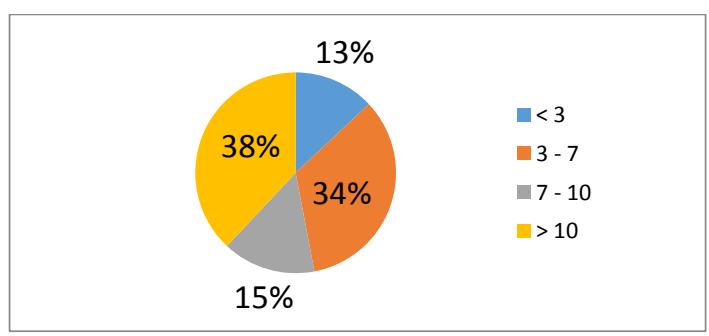

Fig. 6. WTP respondent income (in million IDR).

\section{Conclusion}

For both scenarios, with or without electricity discount, Depok residents respond to finance LFGP is inevitable. Residents' participation rates at the city are quite high which are $86 \%$ and $88 \%$ for the no electricity discount scenario and for the with electricity discount scenario, respectively. While, the most preferred WTP values are in the range of 20,000 to 50,000 IDR and 50,000 to 80,000 IDR for without and with discount scenario, respectively.

This work has been supported partially by PITTA B 2019 Grant funded by DRPM Universitas Indonesia under contract No. NKB-0731/UN2.R3.1/HKP.05.00/2019.

\section{References}

1. H. R. Sudrajat, Mengelola Sampah Kota (Penebar Swadaya, Jakarta, 2007)

2. M. A. Rajaeifar, H. Ghanavati, B. B. Dashti, R. Heijungs, M. Aghbashlo, M. Tabatabaei, Renew. Sust. Energ. Rev. 79, 414-439 (2017)

3. KLH, Report on $3 R$ program Implementation (State Ministry for Environment, Bogor, 2014)

4. Farizal, E. Tammarar, Proceeding of the $7^{\text {th }}$ Conference on Emerging Energy \& Process Technology (CONCEPT 7), Johor Baru, Malaysia (2018) 
5. DEN, Energy Outlook 2014 (Jakarta, Dewan Energi Nasional Republik Indonesia, 2014)

6. KEN, PP No.79 Tahun 2014 (Indonesian Government Regulation No 79 year 2014 on 2025 Energy Mix Policy, 2014)

7. US EPA, https://www.epa.gov/sites/ production/files/2017-06/documents/ landfill_methane_utilization_0.pdf.(2017)

8. B. Amigun, R. Sigamoney, H. V. Blottnitz, Renew. Sust. Energ. Rev. 12, 690-711 (2008)

9. Tribunnews, http://www.tribunnews.com/nasional/2014/02/19/hanya-10-persen-dari438-tempat-pembuangan-sampah-akhir-yang-beroperasi (2014)

10. Farizal, P. J. Hanna, A. Rachman, Proceeding of AUN/SEED-NET Regional Conference on Mechanical and Manufacturing Engineering (RCMME 2013), Kuala Lumpur, Malaysia (2013)

11. D. Trisyanti, M. Helmy, World waste to energy city summit (London, UK, INSWA, 2015)

12. Farizal, R. Aji, A. Rachman, Nasruddin, T. M. I. Mahlia, Makara J. Technol. 21, 3, 153-159 (2017)

13. J. R. Canada, W. G. Sullivan, D. J. Kulonda, J. A. White, Capital Investment Analysis for Engineering and Management ( $3^{\text {rd }}$ ed. Pearson-Prentice Hall, Upper Saddle River, NJ, 2005)

14. E. Mollick, J. Bus. Ventur. 29, 1, 1-16 (2014)

15. J. Green, P. Newman, Energ. Policy 106, 283-293 (2017)

16. E. Vasileiadou, J. C. C. M. Huijben, R. P. J. M. Raven, J. Clean. Prod. 128, 142-155 (2016)

17. P. T. I. Lam, A. O. K. Law, Renew. Sust. Energ. Rev. 60, 11-20 (2016)

18. M. G. Dilger, T. Jovanovic, K-I. Voigt, J. Environ. Manage. 198, 50-62 (2017)

19. R. Afroz, K. Hanaki, K. H. Kurisu, J. Environ. Manage. 90, 492-503 (2015)

20. Y. Yuan, M. Yabe, Environment 1, 190-207 (2014)

21. W. Lu, Y. Peng, C. Webster, J. Zuo, Renew. Sust. Energ. Rev. 47, 233-240 (2015)

22. A. Challcharoenwattana, C. Pharino, Habitat Int. 51, 23-30 (2015)

23. S. Abdullah, P. W. Jeanty, Renew. Sust. Energ. Rev. 15, 2974-2983 (2011)

24. L. Dagher, H. Harajli, Renew. Sust. Energ. Rev. 50, 1634-1642 (2015)

25. S. Siregar, Statistika deskriptif untuk penelitian (Jakarta: PT. Raja Grafindo Persada, 2012)

26. BPMK Depok. Data Gender dan Anak Kota Depok 2014. Depok: Badan Pemberdayaan Masyarakat dan Keluarga Kota Depok. Depok: Badan Pemberdayaan Masyarakat dan Kelurga Kota Depok (2014)

27. BPS. Depok Dalam Angka 2014-2015. Depok: Badan Pusat Statistik (2014)

28. R. Inglehart, C. Haerpfer, A. Moreno, C. Welzel, K. Kizilova, J. Diez-Medrano, M. Lagos, P. Norris, E. Ponarin, B. Puranen (eds), World Values Survey Round FiveCountry-Pooled Datafile Version. JD Systems Institute (2014)

29. ISSP Research Group, International Social Survey Programme: Environment III ISSP 2010. GESIS Data Archive, Cologne (2012) 